\title{
FAKTOR - FAKTOR YANG BERHUBUNGAN DENGAN KEBERHASILAN PROGRAM UPSUS PAJALE DI KECAMATAN SEPUTIH RAMAN KABUPATEN LAMPUNG TENGAH
}

\section{Factors Related to The Successful Implementation of Upsus Pajale Program Seputih Raman of Central Lampung Regency}

\author{
Ayu Marsela ${ }^{1 *}$, Dewangga Nikmatullah ${ }^{2}$, dan Begem Viantimala ${ }^{3}$ \\ ${ }^{1}$ Jurusan Agribisnis, Fakultas Pertanian, Universitas Lampung, Jl. Sumantribojonegoro 1, Bandar Lampung, Lampung, \\ 35134, Indonesia \\ ${ }^{2}$ Program Studi Magister Penyuluh Pertanian dan Komunikasi Pertanian, Fakultas Pertanian, Universitas Lampung, Jl. \\ Sumantribojonegoro 1, Bandar La mpung, 35134, Indonesia \\ ${ }^{3}$ Progra m Studi Penyuluhan Pertanian Fa kultas Pertanian, Universitas Lampung, Jl. Suma ntribojonegoro 1, Bandar \\ Lampung, 35134, Indonesia \\ *email koresponden: ayumarselaa@gmail.com
}

\begin{abstract}
Abstrak
Penelitian ini bertujuan untuk mengetahui pelaksanaan program upsus pajale dikecamatan Seputih Raman dan mengetahui faktor-faktor keberhasilan Program Upsus Pajale dikecamatan Seputih Raman. Da ta dikumpulkan pada bulan Januari 2019 dan melibatkan sebanyak 51 responden dan penelitian ini dilakukan menggunakan metode survei. Metodologi yang digunakan yaitu analisis deskriftif kualitatif dan uji korelasi Rank Spearman. Hasil penelitian menyimpulkan bahwa Program Upsus Pajale berjalan dengan baik, artinya tingkat produktivitas pa di tergo lo ng dala m klasifikasi sedang yaitu 4,94 ton/ha. Fa ktor - fa ktor yang berhubungan nyata dengan pelaksanaan program Upsus Pa ja le adalah alih fungsi, ja ringan irigasi da modal petani, sedangkan fragmentasi lahan tid ak berhubung an nyata dengan pelaksanaan Program Upsus Pajale.
\end{abstract}

Kata kunci: Faktor-faktor, tingkat produktivitas, program

\begin{abstract}
The research studies the implementation of The Upsus Pajale Program in Seputih Raman Districtand studies the success factors in The Upsus Pajale Program in Seputih Raman District. Data collection was conducted in Janua ry 2019 and collected 51 farmer respondents. The research method used was a survey method. The analytical method used is descriptive qualitative analysis and rank rice productivity was classified in the medium classification of 4,94 ton/ha. Factors related to implementation of The Upsus Pajale Program are lans function chan ge, irrigation andfarmer capital, lan fragmentation is not related to the implementation of Upsus Pajale Program.
\end{abstract}

Keywords: Factors, level productivity, program 


\section{PENDAHULUAN}

Indonesia merupakan Negara agraris dengan kondisi tanah dan iklim yang cocok untuk kegiatan pertanian, sehingga mayoritas penduduk Indonesia memiliki matapencaharian sebagai petani. Sektor pertanian memiliki peranan strategis terhadap pembangunan nasional Indonesia. Pada dasarnya, pembangunan nasional adalah proses perubahan struktural di bidang sosial dan ekonomi. Proses perubahan tersebut harus dinamis dan menuju kearah yang lebih baik yang berorientqasi kepada pemenuhan kebutuhan pokok masyarakat. Pangan adalah salah satu kebutuhan pokok utama yang merupakan kebutuhan paling mendasar manusia.

Tanaman pangan adalah satu dari sekian banyak subsektor ekonomi pertanian yang penting dan strategis. Strategis yang dimaksud meliputi kebutuhan mendasar bagi kehidupan masyarakat yang menopang kehidupan para pelaku usaha pertanian di Indonesia lebih dari $60 \%$. Ketahanan dan pertahanan nasional, serta perekonomian nasional akan terlihat langsung dampaknya apabila adanya keberhasilan pembangunan tanaman pangan (Dirjen Tanaman Pangan, 2012.).

Target utama pembangunan petanian salah satunya adalah swasembada pangan. Tercapainya swasembada pangan bagi kehidupan suatu bangsa memiliki arti dan peran penting karena secara otomatis akan menjadi langkah tercapainya ketahanan pangan. Investasi pada sektor pertanian merupakan bentuk kebijakan swasembada pangan yang sangat diperlukan pengkajian lebih dalam dan komprehensif sehingga dapat berdampak baik terhadap ketahanan pangan seperti kemiskinan, aktivitas ekonomi, ketenagakerjaan, hingga konservasi lingkungan (Departemen Pertanian, 2015).

Upsus Pajale merupakan program khusus sebagai usaha bersama untuk mewujudkan swasembada pangan nasional. Peningkatan produksi dan produktivitas tanaman pangan yang ingin ditingkatkan yaitu padi, jagung, dan kedelai. Program ini dilaksanakan untuk mencapai target dengan beragam cara penyelesaian masalah secara terpadu melalui kerjasama partisipasi antara penyuluh pertanian, petani, babinsa, mahasiswa, dan pihak lainnya. Pihak-pihak tersebut merupakan komponen penting dalam mendukung tercapainya target untuk meningkatkan produksi dan produkstivitas pada komoditi padi, jagung, dan kedelai.

Seputih Raman adalah kecamatan dikabupaten Lampung Tengah yang memiliki tingkat luasan lahan dan produksi yang tinggi untuk komoditas padi dan jagung. Berdasarkan (BPS, 2017), Kecamatan Seputih Raman memiliki luas lahan padi sebesar 10.621 ha dan produksi sebesar 62.526 ton. Luas lahan jagung sebesar 1.191 ha dan produksi sebesar 7.872 ton. Kecamatan Seputih Raman memiliki produktivitas padi sawah cukup bervariasi dengan rata-rata berkisar 6 ton/ha. Produktivitas tertinggi terdapat di Desa Rejo Basuki, yaitu sebesar 6,95 ton/ha dan terendah terdapat di Desa Rama Klandungan, yaitu 6,33 ton/ha. Hal-hal yang menjadi faktor bervariasinya produktivitas padi ini dapat berasal dari petani, antara lain luas lahan, teknologi berusahatani, dan saprodi, sedangkan yang berasal dari luar petani, antara lain penyuluhan, pembinaan pemerintah, dan program-program pemerintah salah satunya yaitu program Upsus Pajale.

Program Upsus Pajale memiliki skema yang bisa memberikan peningkatan produksi komoditi padi, jagung dan kedelai, namun untuk mencapai tujuan tersebut maka tergantung kepada pelaksanaannya dilapangan. Berdasarkan uraian diatas, maka dilakukan penelitian terhadap keragaan pelaksanaan program Upsus Pajale dan faktor yang berhubungan dengan keberhasilan program tersebut. Dilakukannya penelitian ini bertujuan untuk 1) Mengetahui pelaksanaan program Upsus Pajale dikecamatan Seputih Raman, Kabupaten Lampung Tengah, 2) Mengetahui faktor-faktor keberhasilan program 
Upsus Pajale dikecamatan Seputih Raman, Kabupaten Lampung Tengah.

\section{METODE PENELITIAN}

Penelitian ini dilaksanakan dikecamatan Seputih Raman, Kabupaten Lampung Tengah. Penentuan lokasi penelitian dilakukan dengan cara purposive (secara sengaja) dan dengan pertimbangan bahwa Seputih Raman adalah kecamatan di Kabupaten Lampung Tengah yang ikut serta pada Program Upsus Pajale dan memiliki tingkat tertinggi produksi padinya. Data penelitian dikumpulkan pada bulan Januari-Maret 2019.

Metode analisis data yaitu deskriftif kualitatif, dan infersal yakni statistik nonparametrik korelasi Rank Spearman untuk menjawab tujuan satu menggunakan metode deskriftif kualitatif dan menjawab tujuan kedua dengan pengujian korelasi Rank Spearman menggunakan rumus (Siegel, 1994):

$$
r s=1-\frac{6 \sum_{i-1}^{n} d i^{2}}{n^{3}}
$$

Keterangan :

$r s$ : penduga koefisien korelasi

di : perbedaan tiap pasangan rank

$\mathrm{n}$ : jumlah responden

Variabel yang terdapat pada penelititan ini yaitu variabel bebas dan terikat (variabel $\mathrm{X}$ dan $\mathrm{Y}$ ). Pengukuran variabel $\mathrm{X}_{1}$ (alih fungsi) $\mathrm{X}_{2}$ (fragmentasi lahan) $\mathrm{X}_{3}$ (modal petani) diukur dengan skor, kisaran skor tertinggi (3) terendah (1). Untuk setiap indikator variabel $\mathrm{X}$ tersebut, jumlah skor yang diperoleh pada setiap variabel lalu di klasifikasikan menjadi 3 kelas yakni rendah, sedang, dan tinggi. Pengukuran variabel $\mathrm{Y}$ yakni tingkat produktivitas, diukur dengan kisaran skor tertinggi (3) terendah (1), lalu di klasifikasikan menjadi 3 kelas yakni rendah, sedang, dan tinggi.

Data penelitian diperoleh dengan wawancara langsung menggunakan kuisioner dan data pendukung didapat dari instansti terkait dan dinas. Populasi adalah kelompoktani yang ikut pada program Upsus Pajale di desa Rejo Basuki, yang terdiri atas 542 petani, dan desa Rama Klandungan, yang terdiri atas 510 petani. Jumlah petani yang menjadi responden di desa Rejo Basuki dan Rama Klandungan ditentukan dengan rumus sebagai berikut, (Sugiarto, 2003).

$n=\frac{N Z^{2} S^{2}}{N d^{2}+Z^{2} S^{2}}$

Keterangan:

$\mathrm{n}$ : jumlah sampel

$\mathrm{N}$ : jumlah anggota dalam populasi (1052)

$\mathrm{Z}$ : derajat kepercayaan $(90 \%=1,64)$

$\mathrm{S}^{2}$ : varian sampel (5\%)

$\mathrm{d}$ : derajat penyimpanan $(5 \%)$

$n=\frac{1052 \cdot 1,64^{2} \cdot 0,05}{1052(0,05)^{2}+1,64^{2}(0,05)}$

$n=51$ responden masyarakat

\section{HASIL DAN PEMBAHASAN}

\section{Pelaksanaan Program Upsus Pajale}

\section{Pendampingan Pelatihan Kelompok Tani}

Tim Upsus pajale dikecamatan seputih raman melakukan pelatihan bagi petani dengan tema "budi daya padi sehat" pelatihan dihadiri perwakilan dari kecamatan seputih raman, baik itu perwakilan dinas pertanian kabupaten lampung tengah, ppl swadaya, serta perwakilan kelompok tani. Pembicara pada kegiatan ini adalah Sutarman (praktisi/petani budidaya tanaman padi sehat). Pada kegiatan ini petani mendapat pengetahuan mengenai cara budidaya pertanian organic dan cara penanganan hama tanaman, petani sangat tergantung terhadap informasi yang diperoleh dari ppl dan penjual saprodi. Sehingga diharapkan dengan mengikuti informasi dan pelatihan tersebut petani tidak salah dalam menerapkan dosis dalam pengendalian hama terhadap tanaman padinya (Wati \& Chazali, 2015). 


\section{Pengawalan Bantuan Alat Mesin Pertanian}

Kecamatan Seputih Raman mendapatkan bantuan berupa peralatan mesin pertanian untuk menunjang kegiatan budidaya tanaman, pemeliharaan, panen, pasca panen, dan pengolahan hasil tanaman. Tahun 2017, pemerintah memberikan bantuan alsintan kepada beberapa kelompok tani yaitu berupa 3 alat hand traktor untuk kelompok tani sari budi jaya, basuki makmur, dan sari bibit (desa Rejo Basuki), serta sinar bahagia, sumber tani dan suka makmur (desa Rama Klambangan).

\section{Pengawasan Pendistribusian Benih Unggul}

Pendistribusian benih unggul secara rutin diberikan setiap tahunnya yaitu berupa benih padi dan penyalurannya dilakukan secara bergilir kesetiap kelompok tani untuk menurunkan biaya produksi petani. Varietas benih yang didistribusikan yaitu ciherang. Penyaluran benih bersubsidi dikecamatan seputih raman terdapat di 2 desa yaitu rejo basuki dan rama klandungan dengan tiap desa mendapatkan $600 \mathrm{~kg}$. Penyaluran di dilaksanakan pada bulan mei kegiatan pengawasan ini secara umum mampu memberikan informasi kepada dinas pertanian tanaman pangan kabupaten lampung tengah bahwa jumlah benih unggul yang disalurkan telah sesuai dengan pengajuan yang ada. Permasalahan yang terkait dengan penyedian bantuan benih unggul adalah terkadang varietas serta kualitas benih tidak dapat berkecambah di atas $80 \%$, sehingga petani harus mengeluarkan biaya lebih untuk melakukan kegiatan penyulaman tanaman

\section{Penyediaan dan Penggunaan Pupuk Berimbang}

Pada awal kegiatan, penyuluh dibantu pendamping upsus melakukan update data kebutuhan pupuk bersubsidi lewat rencana definitif kebutuhan kelompok (RDKK) untuk mengetahui kebutuhan pupuk petani sesuai dengan kenyataan dilapangan. Jenis pupuk bersubsidi yang diberikan pemerintah adalah pupuk kimia dan pupuk organik. Bantuan pupuk kimia diberikan terbatas pada lahan yang dijadikan percontohan disekolah lapang pengelolaan 146 Аyи Marsela et.al. tanaman terpadu (SLPTT), sehingga bagian besar petani mencukupi kebutuhan pupuk dengan membeli dikios pertanian resmi. Bantuan pupuk organik kepada kelompok tani dilakukan secara bergilir setiap tahunnya. Penyaluran pupuk bersubsidi umumnya lancar setiap musimnya. Kegiatan ini mampu memberikan pengetahuan kepada petani mengenai dosis pupuk yang tepat (Sadono, 2008).

Penerapan Musim Tanam dengan Mengikuti Kalender Musim Tanam (Katam)

Kalender musim tanam telah disosialisasikan pleh petugas penyuluh lapangan keseluruh yang ada dan mampu memberikan pengetahuan kepada sebagian besar petani tentang katam dan mendorong petani untuk menerapkan katam padi. Pelaksanaan katam tidak sepenuhnya berhasil, seperti budidaya padi di kecamtan seputih raman tidak dapat serentak sehingga pada saat ada petani yang sedang panen dan saat bersamaan ada pula yang sedang tanam. Kondisi ini menyebabkan siklus hama dan penyakit berlangsung secara berkelanjutan. Permasalahan lain yang dihadapi dalam penerapan katam adalah kondisi iklim yang semakin sulit diprediksi dan diantisipasi sehingga jadwal musim tanam berubah ubah setiap tahun. Pola budidaya untuk mengoptimalkan fungsi lahan dikabupaten lampung tengah adalah pola jajar legowo. Penanaman padi dengan sistem jajar legowo ternyata dapat meningkatkan produktivitas padi.

\section{Faktor yang Berhubungan dengan Keberhasilan Program Upsus Pajale}

\section{Alih Fungsi Lahan (X1)}

Perubahan fungsi lahan baik itu sebagian atau keseluruhan dari suatu fungsi ke fungsi lainnya disebut dengan alih fungsi lahan. Tingkat alih fungsi lahan dikecamatan Seputih Raman terlihat pada Tabel 1.

Berdasarkan penelitian yang telah dilakukan alih fungsi lahan masuk dengan nilai rata-rata 13,51 masuk kedalam klasifikasi sedang. Menurut badan penyuluh pertanian (BPP), kecamatan Seputih

DOI: $10.25077 /$ joseta.v2i2.236 
Raman merupakan salah satu lumbung pangan Berdasarkan penelitian yang telah dilakukan jaringan penghasil padi sawah dikabupaten Lampung Tengah. irigasi dengan nilai rata-rata sebesar 8,46 masuk

Tabel 1. Tingkat alih fungsi lahan dikecamatan Seputih Raman

\begin{tabular}{llll}
\hline Skor & Klasifikasi & $\begin{array}{l}\text { Jumlah Responden } \\
\text { (Jiwa) }\end{array}$ & Persentase (\%) \\
\hline $10,17-12,81$ & Rendah & 24 & 47,06 \\
$12,82-15,46$ & Sedang & 15 & 29,41 \\
$15,47-18,11$ & Tinggi & 12 & 23,53 \\
\hline Jumlah & 13,51 (Sedang) & 51 & 100 \\
Rata-rata & & \\
\hline
\end{tabular}

\section{Fragmentasi Lahan (2)}

Proses terjadinya pembagian suatu lahan pertanian menjadi unit yang berukuran lebih kecil disebut dengan fragmentasi lahan. Data fragmentasi lahan kedalam klasifikasi baik. Sistem pengairan pertanian dikecamatan seputih raman merupakan sistem pengairan irigasi tersier, sehingga petani dalam melaksanakan program pajale sangat tergantung pada sistem irigasi yang ada.

Tabel 2. Fragmentasi lahan dikecamatan Seputih Raman

\begin{tabular}{llll}
\hline Skor & Klasifikasi & $\begin{array}{l}\text { Jumlah Responden } \\
\text { Jiwa }\end{array}$ & Persentase (\%) \\
\hline $5,00-8,72$ & Rendah & 41 & 80,39 \\
$8,73-12,45$ & Sedang & 6 & 11,76 \\
$12,46-16,18$ & Tinggi & 4 & 7,84 \\
\hline Jumlah & & 51 & 100 \\
Rata-rata & 7,84 (Rendah) & & \\
\hline
\end{tabular}

dikecamatan Seputih Raman terlihat pada Tabel 2.

Berdasarkan penelitian yang telah dilakukan fragmentasi lahan dengan nilai rata-rata 7,84 termasuk kedalam klasifikasi rendah. Fragmentasi lahan dianggap petani merupakan hal yang tidak efektif untuk diterapakan, yang pada akhirnya banyak memberikan kerugian terhadap petani dalam berusahatani.

\section{Jaringan Irigasi $(x 3)$}

Jaringan yang berfungsi sebagai prasarana penyaluran air pada suatu petak disebut dengan jaringan irigasi. Data jaringan irigasi dikecamatan Seputih Raman terlihat pada Tabel 3.

\section{Modal Petani (x4)}

Modal petani adalah sarana prasarana usaha yang meliputi fix-cost dan variable cost pada program Upsus Pajale. Menurut hasil penelitian, modal petani masuk dalam klasifikasi sedang dengan rata- rata sebesar 4.467.968. Sebagian besar petani menggunakan tenaga kerja dari keluarga sendiri. Bibit yang diperoleh dari program pajale, sehingga hal ini mempengaruhi modal yang digunakan petani dalam melakukan usaha tani. 
Tabel 3. Jaringan irigasi dikecamatan Seputih Raman

\begin{tabular}{llll}
\hline Jaringanirigasi (Interval Skor) & Klasifikasi & $\begin{array}{l}\text { Jumlah Responden } \\
\text { (Orang) }\end{array}$ & Persentase (\%) \\
\hline $4,28-6,33$ & Kurang & 10 & 19,61 \\
$6,34-8,39$ & Cukup & 16 & 31,37 \\
$8,40-10,45$ & Baik & 25 & 49,02 \\
\hline Jumlah & & 51 & 100 \\
Rata-rata & 8,46 & (Tinggi) & \\
\hline
\end{tabular}

Tabel 4. Modal petani di ke Kecamatan Seputih Raman

\begin{tabular}{llll}
\hline Modal petani (Rp) & Klasifikasi & Responden(Orang) & Persentase (\%) \\
\hline $1.164 .905-3.716 .603$ & Rendah & 19 & 37,25 \\
$3.716 .604-6.268 .302$ & Sedang & 22 & 43,14 \\
$6.268 .303-8.820 .001$ & Tinggi & 10 & 19,61 \\
\hline Jumlah & & 51 & 100 \\
Rata - rata & 4.467 .968 & (Sedang) & \\
\hline
\end{tabular}

Keberhasilan Program Upsus Pajale dikecamatan Seputih Raman Kabupaten Lampung Tengah

\section{Raman}

Produktivitas Tanaman Padi di Seputih

Produktivitas adalah produksi yang dihasilkan dibagi luas lahan dalam satu musim tanam. Data sebaran petani responden berdasarkan produktivitas padi pada Program Upsus Pajale dikecamatan Seputih Raman terlihat pada Tabel 5. klasifikasi sedang artinya sudah cukup baik dalam pelaksanaannya.

\section{Hubungan Variabel $(X)$ dengan Variabel $(Y)$}

Hubungan antara variabel $X$ faktor yang berhubungan dengan tingkat keberhasilan program upsus pajale dengan variable $\mathrm{Y}$ keberhasilan program pajale dianalisis dengan menggunakan program SPSS 21 untuk melihat apakah terdapat hubungan saling terkait antar variable atau tidak memiliki hubungan sama sekali. Hasil pengujian

Tabel 5. Sebaran petani responden berdasarkan produktivitas padi pada program upsus pajale dikecamatan Seputih Raman Kabupaten Lampung Tengah

\begin{tabular}{llll}
\hline Produktivitas (ton/ha) & Klasifikasi & Jumlah Responden & Persentase (\%) \\
\hline $3,80-4,87$ & Rendah & 22 & 43,14 \\
$4,88-5,95$ & Sedang & 23 & 45,10 \\
$5,96-7,03$ & Tinggi & 6 & 11,76 \\
\hline Jumlah & & 51 & 100 \\
Rata-rata & 4,94 (Sedang) & & \\
\hline
\end{tabular}

Berdasarkan penelitian yang telah dilakukan, diperoleh hasil produktivitas tanaman padi tergolong dalam klasifikasi sedang yaitu dengan nilai 4,94\%. Berdasarkan penelitian (Rizqi , Gitosaputra , \& Silvianti, 2019) hasil penelitian ini tergolong dalam 148 Ayи Marsela et.al. faktor-faktor keberhasilan program upsus pajale terlihat pada Tabel 6 .

Berdasarkan Tabel 6, hasil perhitungan dalam mencari nilai signifikan pada pengujian korelasi 
Tabel 6. Hasil analisis faktor yang diduga berhubungan dengan keberhasilan program pajale dikecamatan Seputih Raman, Kabupaten Lampung Tengah.

\begin{tabular}{|c|c|c|c|c|}
\hline No & Variabel $\mathrm{X}$ & Variabel Y & Koefisien Korelasi (rs) & Sig (2-tailed) \\
\hline 1 & Alih fungsilahan(X1) & \multirow{4}{*}{ Keberhasilan program Pajale } & $0,40 * *$ & 0,00 \\
\hline 2 & Fragmentasi lahan (X2) & & $-0,08$ & 0,59 \\
\hline 3 & Jaringan irigasi (X3) & & $0,32 *$ & 0,03 \\
\hline 4 & Modal petani(X4) & & $0,54 * *$ & 0,00 \\
\hline
\end{tabular}

Keterangan:

$\mathrm{r}_{\mathrm{s}}$ : penduga koefisien korelasi

** : berhubungan sangat nyata di taraf kepercayaan $99 \%(\alpha=0,01)$

* : berhubungan nyata di taraf kepercayaan $95 \%(\alpha=0,05)$

tn : tidak nyata di taraf kepercayaan $95 \%$ dan $99 \%$

Rank Spearman menunjukkan bahwa variabelvariabel yang berhubungan nyata dengan faktorfaktor keberhasilan program upsus pajale adalah alih fungsi lahan, jaringan irigasi, dan modal pertanian. Sedangkan untuk variabel fragmentasi lahan tidak berhubungan nyata dengan keberhasilan program upsus pajale.

\section{Hubungan Antara Alih Fungsi Lahan Dengan Keberhasilan Program Pajale}

Alih fungsi lahan diduga berhubungan nyata dengan keberhasilan program pajale hasil pengujian hipotesis hubungan antara alih fungsi lahan (X1) dengan keberhasilan program pajale (Y). Dengan penggunaan uji korelasi Rank Spearman didapatkan hasil 0,0397 dan nilai signifikan yaitu $0,004(<\alpha=$ 0,05). Sehingga dapat disimpulkan bahwa $\mathrm{H}_{1}$ diterima, artinya alih fungsi lahan memiliki hubungan signifikan dengan keberhasilan program upsus pajale, artinya semakin tinggi tingkat alih fungsi lahan maka semakin rendah keberhasilan program upsus pajale.

\section{Hubungan Antara Fragmentasi Lahan Dengan Keberhasilan Program Pajale}

Fragmentasi lahan diduga berhubungan nyata dengan keberhasilan program pajale hasil pengujian hipotesis hubungan antara alih fungsi lahan (X2) dengan keberhasilan program pajale (Y). Dengan penggunaan uji korelasi Rank Spearman didapatkan hasil $-0,076$ dan nilai signifikan yaitu $-0,594(>\alpha=$ 0,05). Sehingga dapat disimpulkan bahwa $\mathrm{H}_{1}$ ditolak, artinya fragmentasi lahan memiliki hubungan signifikan dengan keberhasilan program upsus pajale, artinya semakin tinggi tingkat fragmentasi lahan maka semakin rendah keberhasilan program upsus pajale.

\section{Hubungan Modal Jaringan Irigasi Dengan Keberhasilan Program Pajale}

Jaringan irigasi diduga berhubungan nyata dengan keberhasilan program pajale hasil pengujian hipotesis hubungan antara alih fungsi lahan (X3) dengan keberhasilan program pajale (Y). Dengan penggunaan uji korelasi Rank Spearman didapatkan hasil 0,0315 dan nilai signifikan yaitu $0,025(<\alpha=$ 0,05). Sehingga dapat disimpulkan bahwa $\mathrm{H}_{1}$ diterima, artinya jaringan irigasi memiliki hubung an signifikan terhadap keberhasilan program upsus pajale, artinya semakin baik suatu jaringan irigasi maka semkain tinggi tinmgkat keberhasilan program Upsus pajale. 


\section{Hubungan Modal Petani Dengan Keberhasilan Program Pajale}

Modal petani diduga berhubungan nyata dengan keberhasilan program pajale hasil pengujian hipotesis hubungan antara alih fungsi lahan (X4) dengan keberhasilan program pajale (Y). Dengan penggunaan uji korelasi Rank Spearman didapatkan hasil 0,0539 dan nilai signifikan yaitu $0,00(<\alpha=$ 0,05). Sehingga dapat disimpulkan bahwa $\mathrm{H}_{1}$ diterima, artinya modal petani memiliki hubungan signifikan dengan keberhasilan program upsus pajale, berarti semakin tinggi modal petani maka semakin tinggi keberhasilan program upsus pajale.

\section{KESIMPULAN}

Berdasarkan hasil penelitian dan pembahasan mengenai faktor-faktor yang berhubungan dengan pelaksanaan keberhasilan program upsus pajale dikecamatan Seputih Raman Kabupaten Lampung Tengah dapat disimpulkan bahwa program upsus pajale sudah berjalan baik yang dapat dilihat dari tingkat produktivitas padinya, yaitu 4,96 ton/ha yang tergolong kedalam klasifikasi sedang. Faktor-faktor yang berhubungan nyata dengan pelaksanaan keberhasilan program upsus pajale adalah alih fungsi lahan, jaringan irigasi, dan modal petani. Sedangkan fragmentasi tidak memiliki hubungan nyata dengan keberhasilan program Upsus pajale.

Perlunya perhatian intens dan evaluasi program upsus pajale dari pemerintah agar program upsus pajale kedepannya dapat lebih mensejahterakan kehidupan petani.

\section{UCAPAN TERIMA KASIH}

Terimakasih disampaikan kepada para petani dan pihak terkait yang sudah membantu memberikan informasi dan data yang diperlukan pada penelitian ini, terimakasih juga disampaikan kepada pembimbing dosen prodi agribisnis yang telah membimbing selama pelaksanaan penelitian.

\section{DAFTAR PUSTAKA}

BPS. (2017). Lampung Dalam Angka 2018. Lampung: Badan Pusat Statistik.

Departemen Pertanian. (2015). Rencana Strategis $2015-$ 2019 Peraturan Mentri Pertanian. . Jakarta.

Dirjen Tanaman Pangan. (2012.). Pedoman Pelaksanaan Program Peningkatan Produksi, Produktivitas, dan Mutu Tanaman Pangan untuk Mencapai Swasembada dan Swasembada Berkelanjutan. Kementerian Pertanian, Dirjen Ta naman Pangan, Jakarta.

Rizqi , H., Gitosaputra , S., \& Silvianti , S. (2019). Partisipasi Anggota Kelompok Tani dalam Program Upaya Khusus Pa di Ja gung dan Kedelai dikeca matan Metro Barat Kota Metro. Jurnal Ilmu-IlmuAgribisnis, $7(1)$.

Sadono, D. (2008). Pemberdayaan Petani: Paradigma Baru Penyuluhan Pertanian di Indonesia. Jurnal Penyuluhan, 4(1), 65-74.

Siegel, S. (1994). Statistik Non Parametrik untuk IlmuIlmu Sosial. Jakarta: PT Gra media.

Sugiarto. (2003). Teknik Sampling. Jakarta: Gramedia Pustaka Utama.

Wati, H., \& Chazali, C. (2015). Sistem Pertanian Padi Skala Kecil Indonesia dalam Perspektif Efisiensi Sosial. Jurnal Analasis Sosial, 19(1), 41-56. 